\title{
The 2020 APSA Awards
}

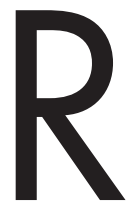

ecognizing excellence in the profession is one of the most important roles of APSA. Through the service of member committees who review nominations, APSA confers awards for the best dissertations, papers and articles, and books in the various subfields of the discipline as well as for career achievement in research, teaching, and service to the discipline. The 2020 APSA Awards were presented at the virtual meeting on Wednesday, September 9.

\section{FRANK J. GOODNOW AWARD}

The Frank Johnson Goodnow Award was established by the APSA Council in 1996 to honor service to the community of teachers, researchers, and public servants who work in the many fields of politics. Frank J. Goodnow, the first president of the American Political Science Association, a pioneer in the development of judicial politics, and former president of Johns Hopkins University, is an exemplar of the public service and volunteerism that this award represents. Award Committee: Arlene W. Saxonhouse, chair, University of Michigan; James P. Pfiffner, George Mason University; Michele L. Swers, Georgetown University. Recipient: M. Kent Jennings, University of California, Santa Barbara.

Citation: Professor Jennings has had a distinguished career of service to the political science community, he has been an intellectual leader in the field, and he has mentored many of today's leading scholars.

Jennings was president of APSA (1997-98) and served APSA on a variety of committees including, among others, the Program Committee and the Committee on the Status of Women. He has been a member of multiple editorial boards including the American Journal of Political Science, the Journal of Politics, the Public Opinion Quarterly, and Women and Politics. He was also president of the International Society of Political Psychology and vice president of the Midwest Political Science Association. Jennings cofounded the Inter-University Consortium for Political and Social Research (ICPSR) and was its associate director for 20 years. He was also a founding member of the International Society for Political Psychology (ISPP) and shares the credit for creating an international infrastructure that brings together political psychologists from multiple disciplines and provides a journal, annual meetings and annual training workshops. For these efforts, Jennings received the Warren E. Miller Prize for Outstanding Career of Intellectual

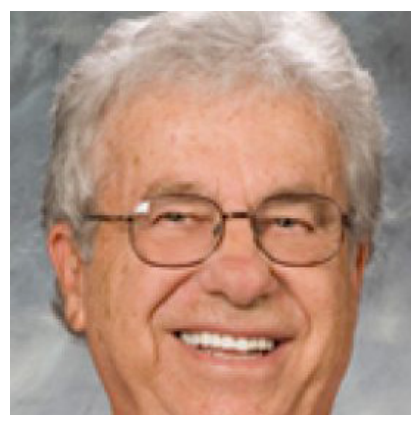

Accomplishment and Service to the Profession from APSA's organized section on Elections, Public Opinion and Voting Behavior, the Miller Award for Meritorious Service to the Social Sciences from the ICPSR, and the Nevitt Sanford Award for Distinguished Contribution to Political Psychology from the ISPP.
Professor Jennings has been a leader in the fields of political socialization, political psychology, and women and politics. His books and numerous articles in leading journals in political science opened the field to the study of the early sources of political attitudes and behavior and the changes in those attitudes and behavior over time. The significance of his scholarship has been recognized by his election to the American Academy of Arts and Sciences and prestigious fellowships at the Center for Advanced Studies in the Behavioral Sciences and the Netherlands Institute for Advanced Studies in the Humanities and Social Sciences.

Generations of doctoral students have benefited from Jennings's mentorship, especially a large number of female scholars. When there were few women in the field and when they faced significant obstacles to professional success, Jennings fostered their careers, bringing them in as research assistants and coauthors. In doing so, he supported the first generation of gender and politics scholars, helping to create a new subfield in the profession. For this, he was named "mentor of distinction" twice by the Women's Caucus for Political Science.

In recognition of his years of service to the profession, for his path-breaking scholarship, and his mentorship of scores of younger scholars, Professor Jennings is a worthy recipient of the Frank J. Goodnow Award.

\section{BARBARA SINCLAIR AWARD}

This award commemorates the life and scholarship of renowned scholar of legislative politics Barbara Sinclair. Each year a speaker will be selected to deliver the lecture, held at American University. The inaugural Barbara Sinclair Lecture took place in fall 2018. Speaker selection recognizes achievement in promoting understanding of the US Congress and legislative politics. The lecture and speaker honorarium are cosponsored by the Center for Congressional and Presidential Studies, School of Public Affairs, American University. Award Committee: David C. Barker, co-chair, American University; Meghan McConaughey, co-chair, American Political Science Association; Lauren Cohen Bell, Randolph-Macon College; Jason P. Casellas, University of Houston; Michelle Chin, The Archer Center. Recipient: Richard Hall, University of Michigan.

Citation: Professor Rick Hall is an esteemed scholar studying the wide range of issues involved in making sense of Congress. His work exemplifies the criteria for this award, promoting an understanding of the US Congress and legislative politics. In selecting this year's Barbara Sinclair Lecturer, the selection committee particularly noted that Rick's Participation in Congress, which won the American Political Science Association's 1997 Richard Fenno Prize, provides the foundation upon which a successive generation of legislative scholars has built its own research. Participation in Congress remains an essential part of the legislative studies canon, alongside and in the spirit of Barbara Sinclair's Unorthodox Lawmaking, helping us to understand the impact of 
institutional structures and rules on policy outcomes and on the political behavior of members of Congress.

Rick earned his bachelor's degree from the University of lowa, and his masters and doctorate degrees from the University of North Carolina, Chapel Hill. Upon completing his

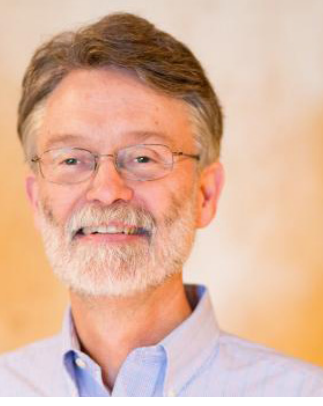

$\mathrm{PhD}$, he took a faculty position at the University of Michigan, Ann Arbor, where he has continued his work since. Rick's scholarship is cited frequently, and in addition to winning the Fenno Prize, has been recognized with the American Political Science Association's Jack L. Walker Award, and the Midwest Political Science Association's Pi Sigma Alpha Award. In 1987-88, Rick served as an APSA Congressional Fellow in the office of Senator Tom Daschle, and over the course of his career, his scholarship has reflected the deep insider understanding of the ways in which Congress works that was fostered during his time as a congressional fellow. As his nominator wrote, "On each topic he works on, his research is one of the authoritative pieces. When scholars ask why individual legislators are (not) working on certain policies or why interest groups wield power in Congress, we turn to Rick's research as the foundational arguments that help provide our answers. Without his insights, our basic understanding of Congress on multiple issues would be wanting."

\section{Career Awards}

\section{APSA COMMUNITY COLLEGE FACULTY AWARD}

The APSA Community College Faculty Award is awarded for excellence in teaching, mentoring, community engagement, governance, and/or research by a community college faculty member in the profession. Award Committee: Rachel Bzostek Walker, chair, Collin College; Eric C. Schwartz, Hagerstown Community College; Christina Sciabarra, Bellevue College. Recipient: Erin Richards, Cascadia College.

Citation: Erin Richards is simply an outstanding example of a dedicated community college professor and engaged member of APSA. She is a tireless advocate for community college faculty, an empathetic mentor, an inspired teacher, and a skilled networker who has assisted countless colleagues in their professional development.

After receiving a BA in political science from Mount Holyoke College, Professor Richards continued graduate studies at Washington State University. Since 2007, she has been on the faculty at Cascadia College in Bothell, WA, where she currently serves as the division coordinator of social sciences. In addition to her duties as division coordinator at the college, Richards serves on the college's Program Assessment Committee and the Human Participants Research Review Board. She also serves as a political science liaison with local high schools and college coordinator for the political science discipline.

Professor Richards is an innovative and collaborative teacher who has worked with multiple programs and departments at Cascadia College. Professor Richards collaborated with colleagues from other departments to create the Bachelor of Applied Science in Sustainable Practices, an interdisciplinary degree focused on teaching students how to help organizations utilize sustainability strategies. She created the courses related to environmental policy and politics and teaches them as part of the program.

Professor Richards is truly a mentor to her colleagues and is responsible for bringing dozens of community college faculty to the APSA. She has supported faculty in joining committees, presenting at conferences, and advocating for community colleges within the association and the discipline at large. She is a fixture at the annual meeting and Teaching and Learning Conference (TLC) and actively reaches out to new faculty, welcomes them to the organiza-

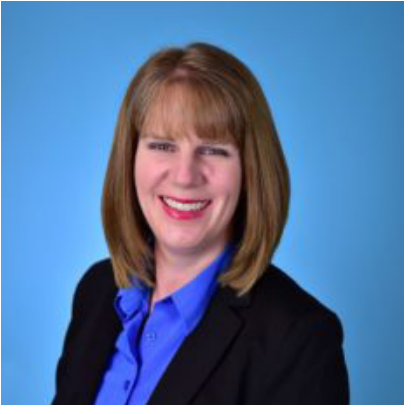
tion, and finds ways to get them engaged.

Professor Richards's nomination was supported by numerous faculty, including a nomination letter signed by nine faculty from different institutions. They wrote, "Erin Richards exemplifies a community college faculty who talks-the-talk and walks-thewalk. Her advocacy on behalf of community college faculty in teaching and in the discipline serves as an example to her students who see in her a stellar example of someone who makes real the spirit of the discipline."

Aside from her work within her own institution, the committee also cited Professor Richards's service to the discipline. In 2017, Professor Richards was the first community college faculty to be elected to the APSA Council and last year she was a key mover getting the Community College Caucus organized. She currently sits on the editorial board of the Journal of Political Science Education and serves on the policy committee of the APSA Political Science Education and Audit Committee.

Professor Richards has also been active professionally in the Pacific Northwest region, serving on the executive committee of Pacific Northwest Political Science Association, including terms as secretary and president.

\section{APSA DISTINGUISHED AWARD FOR CIVIC AND COMMUNITY ENGAGEMENT}

The APSA Distinguished Award for Civic and Community Engagement is given for significant civic or community engagement activity by a political scientist which merges knowledge and practice and has an impact outside of the profession or the academy. Award Committee: Amy Cabrera Rasmussen, chair, California State University, Long Beach; Elizabeth Beaumont, University of California, Santa Cruz; Ethan Frey, Ford Foundation; Christopher F. Karpowitz, Brigham Young University; Veronica Reyna, Houston Community College. Recipient: Marc Howard, Georgetown University.

Citation: While we were lucky to have many outstanding 
nominees representing a diverse and impactful array of civic and community engagement efforts in this first year of award selection, the committee felt that Professor Howard's work uniquely manifested into a set of overlapping and interrelated impacts-local and national, individual and institutional-driven by a unified mission focused on addressing systemic injustices and promoting greater social equity.

The Georgetown Prisons and Justice Initiative, which Professor Howard founded in 2016 and presently leads, was created "in order to respond to the dual crisis of incarceration and recidivism. It brings together leading scholars, practitioners, and students to tackle the problem of mass incarceration-one of the most crucial moral and political issues of our time." The initiative has several prongs, including a course taught in the District of Columbia jail that brings together students from Georgetown and those incarcerated. It also offers a lecture series and credit-bearing study group that provides a pathway to a bachelor's degree at the DC jail known as the Prison Scholars Program. Also included is the Georgetown Pivot Program, which incorporates compensated job

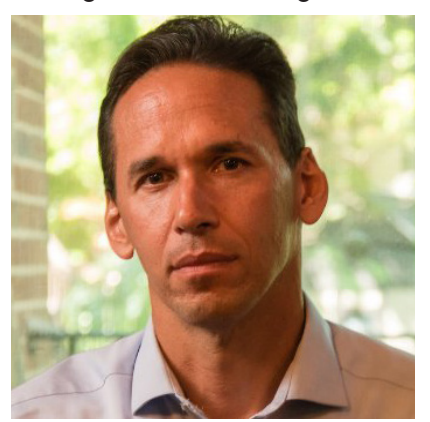

training, academic courses, and internships for newly released prisoners. Professor Howard and PJI also played a key role in working with the DC Mayor's Office on Returning and Citizen Affairs and its partners to create a groundbreaking Paralegal Fellowship Program that trains, certifies and employs previously incarcerated men and women

for paralegal positions in local high-profile law firms. Letters of support also showcase Howard's personal involvement and advocacy for many of those wrongfully convicted, going on to serve as a mentor for these individuals, something to which they personally attest. The committee also commends the strength of his related teaching and research, and highlights the fact that his impactful applied work is informed by and informs his research, including his 2017 book Unusually Cruel: Prisons, Punishment and the Real American Exceptionalism.

Those nominating and supporting the consideration of Professor Howard's efforts persuasively affirmed his indispensable role in these endeavors' implementation and impact. As one supporting letter noted, "Marc used his unique skill to bring together different sectors (academic, government, business, and non-profit) for some of the most innovative and deeply impactful programs in the country," noting that Professor Howard has a "vision and ability to use academics to lead many disparate stakeholders to the same goal." Playing a pivotal role in facilitating these types of unique collaborations is a clear example of the kind of productive partnerships that the Distinguished Award for Civic and Community Engagement seeks to recognize.

Professor Howard and his students have also researched and provided public exposure (and in many cases exoneration and release) for many wrongfully incarcerated individuals, a large share of whom are people of color. His efforts are asserted to have contributed to the greater integration of the Georgetown campus with the DC community. Additionally, his scholarship and advocacy through PJI have illuminated the larger racial injustices of incarceration and provided support for prison reform, all the while linking educational opportunity and access to these efforts. As such, the committee found a particular strength of Professor Howard's work to be the evidence supplied of the project's contribution to matters of diversity, inclusion, and equity.

We applaud Professor Howard's work on the Georgetown Prison Justice Initiative and look forward to his future work in this area. As the awardee, in addition to a $\$ 1,000$ honorarium, APSA and the Task Force on New Partnerships will also provide funds for Professor Howard to organize an activity to advance civic and community engagement within the discipline at the 2021 Annual Meeting.

\section{APSA DISTINGUISHED TEACHING AWARD}

The APSA Distinguished Teaching Award honors the outstanding contribution to undergraduate and graduate teaching of political science at two- and four-year institutions. The contribution may span several years or an entire career, or it may be a single project of exceptional impact. Award Committee: Rachel Paine Caufield, chair, Drake University; Meredith Rolfe, University of Massachusetts, Amherst; Jose D. Villalobos, University of Texas at El Paso. Recipient: Peter Lindsay, Georgia State University.

Citation: Dr. Lindsay's record is distinguished by three prominent and exceptional qualities. First, his dedication to teaching and learning is exhibited across multiple academic audiences throughout the community. Based on two years of independent teaching in jails and prisons, Dr. Lindsay cofounded the Georgia State Prison Education Project in 2016, where he teaches in state and federal penitentiaries and halfway houses and creates opportunities for interaction between current or former inmates and Georgia State University students. He has also taught in high schools and nursing homes. Nominators praise the sincere curiosity that he brings to the exploration of thorny moral and policy questions within these various settings, and applaud his authenticity, candor, directness, expertise, and compassion. As a teacher and scholar, Dr. Lindsay bridges the academic world and the practical concerns that animate philosophical principles.

Second, Dr. Lindsay has produced original scholarship on the practice of teaching, and has done so in addition to a vibrant record of scholarly publication within the subfield of political philosophy. His 2018 book, The Craft of University Teaching (University of Toronto Press), is evidence of a thoughtful approach to innovation based on experiences with diverse audiences, and nominators comment that his scholarship of teaching and learning demonstrates a deep and sustained attention to what effective teaching can achieve. He has been a lifelong student and respected resource on pedagogical approaches, generously sharing his perspectives with colleagues and peers across the country and around the world.

Finally, Dr. Lindsay's record of teaching excellence has been sustained over a long period of time. Dr. Lindsay has received numerous accolades throughout

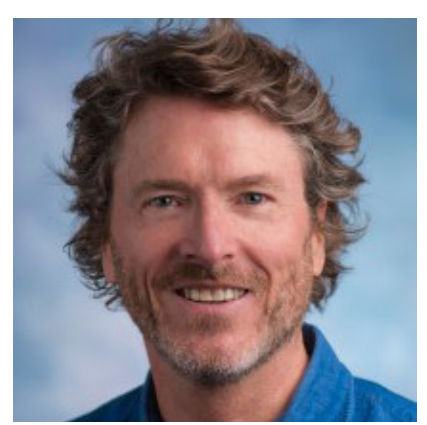


his career, including the Georgia Board of Regents Hall of Fame teaching award, which spans all 37 campuses of the University System of Georgia. As one nominator writes, "He has instilled the habit of critical thought and philosophical inquiry in a generation of students-many of whom happened into his classroom on the strength of his reputation as a teacher and left with a deep appreciation of the practical importance of what classical political theory in the daily practice of politics."

For these reasons, Dr. Peter Lindsay exemplifies excellent teaching, and he is richly deserving of this additional honor, the 2020 APSA Distinguished Teaching Award.

\section{JOHN GAUS AWARD}

The John Gaus Award and Lectureship honors the recipient's lifetime of exemplary scholarship in the joint tradition of political science and public administration and, more generally, recognizes and encourages scholarship in public administration. Award Committee: Anne Khademian, chair, Virginia Tech; Claudia N. Avellaneda, Indiana University; Anthony Bertelli, Pennsylvania State University/Bocconi University. Recipient: John Bryson, Humphrey School of Public Affairs, University of Minnesota.

Citation: Professor Bryson's "lifetime of exemplary scholarship in the joint tradition of political science and public administration" has not only made innovative, impressive and indelible scholarly contributions to the study and practice of political science and public administration, and stimulated and advanced scholarship in public administration, but has inspired practice in impactful and meaningful ways.

Professor Bryson's scholarly contributions bridge and integrate our aspirations for democratic inclusion and representation with organizational capacity building, sustainability, and flexi-

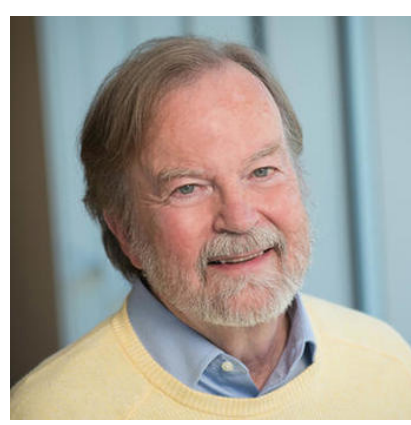

bility to translate aspirations into action. In her nomination letter for Professor Bryson, supported by the leadership and management faculty of the Humphrey School, Dean Laura Bloomberg highlights the five major areas of scholarship that Professor Bryson has significantly shaped and impacted over his career: "Strategic planning and management of public and nonprofit organizations; leadership and policy change, especially in shared-power, multi-sector, no-one-wholly-in-charge situations; collaboration, and especially cross-sector collaboration; stakeholder identification, analysis, and management; and public value and public values." Motivated to understand, "How... people in government and nonprofit settings figure out what they think they ought to want and how to get it," and how to "help" them do so, Professor Bryson's work demonstrates that it is not enough to lead strategically, across boundaries, sectors and jurisdictions, and to take action collaboratively with multiple stakeholders, but that service in the public and nonprofit sectors, in particular, requires continuous questioning and grappling with the creation of public value-what is being created, why, how and toward what end? -in highly contested spaces where the opportunity for meaningful participation can result in the most impactful outcomes. From the award winning five-edition book Strategic Planning for Public and Nonprofit Organizations, to the award winning Leadership for the Common Good, coauthored with Barbara Crosby, to the most downloaded paper in the International Public Management Journal since its 2009 publication, "Understanding Strategic Planning and the Formulation and Implementation of Strategic Plans as a Way of Knowing: The Contributions of Actor-Network Theory," Professor Bryson's work continuously advances theory with a clarity of context and circumstances, embedded in the iterative effort to manifest public value, that is informed by years of applying his work to the governing challenges in Minnesota, North America, and across the globe. Books and journal articles abound, each with a quality of purpose and insight that is widely recognized through nearly 22,000 citations and awards too numerous to list.

Receipt of the John Gaus Award follows a number of additional distinguished awards in the fields of public administration and political science, including the 2019 Keith Provan Award (jointly with Barbara C. Crosby) from the Academy of Management, the 2018 H. George Frederickson Award from the Public Management Research Association, the 2011 Dwight Waldo Award from the American Society for Public Administration, and the 2008 Charles H. Levine Memorial Award given jointly by the Network of Schools of Public Policy, Affairs, and Administration and the American Society for Public Administration, among others.

In a year of pandemic and protest, of deep divisions and distrust, where technology connects us but a shared vision eludes us, Professor Bryson's work provides the framework and the tools for doing the hard work of tackling our problems one step at a time, building consensus around thoughtful solutions, and seeing the value of difficult collaboration as the fabric of our democracy. The John Gaus Award and Lectureship Committee is delighted to recognize a scholar for our times and all times, Professor John M. Bryson.

\section{HUBERT H. HUMPHREY AWARD}

The Hubert $\mathrm{H}$. Humphrey Award is awarded annually in recognition of notable public service by a political scientist. The award is intended to honor former Vice President Humphrey's distinguished career and life of public service. Award Committee: Susan Herbst, chair, University of Connecticut; Bruce W. Jentleson, Duke University; Philippe Lagasse, University of Ottawa. Recipient: Tom Wolf, Governor of Pennsylvania.

Citation: Tom Wolf is the 47th Governor of the Commonwealth of Pennsylvania, a position he has held since 2015. Wolf is an extraordinary example of a successful private sector executive who was able to make the difficult leap to high public office. His excellence in public service underscores the importance of bringing experienced business leaders into government, since they are often highly effective in boosting economic growth for citizens of their states.

Dr. Wolf has a wonderfully

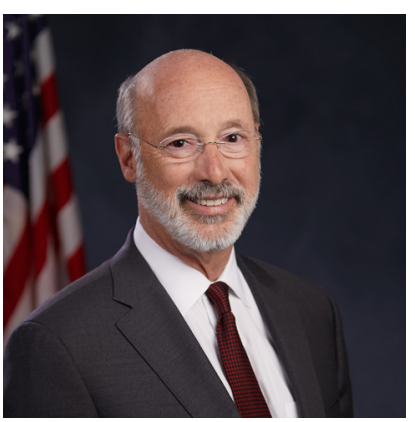


diverse background. After growing up in York County, he attended college at Dartmouth but took a break to join the Peace Corps, serving as an agricultural worker in India. After his work in the corps he returned to Dartmouth, finished his studies, and went on to earn a Master's degree at the University of London. He then enrolled at the Massachusetts Institute of Technology, where he earned a doctorate in political science. His award-winning dissertation is entitled "Congressional Sea Change: Conflict and Organizational Accommodation in the House of Representatives, 1878-1921."

Instead of pursuing an academic position, Dr. Wolf decided instead to return to his small hometown and join the family lumber distribution business. There, he had to start low in the organization and work his way to higher positions. He once quipped, "I was the only PhD forklift operator in York County at the time, I'm pretty sure."

Over the years, he rose in the company and eventually bought the business in 1985. He sold the business to serve as Secretary of Revenue under Governor Rendell in 2005. After three years, he again bought the Wolf Organization and led it back to success from difficult times, diversifying production and improving conditions for the large workforce.

Dr. Wolf has been a successful governor, restoring funds to education, supporting small businesses, and expanding Medicaid to cover hundreds of thousands of Pennsylvanians who were without health insurance. He has made the fight against opioid addiction a high priority, working with the medical community on imaginative ways to reduce dependence and save lives.

Like all governors in the United States today, Dr. Wolf has been faced with the most extraordinary health and financial challenges since the Great Depression. Pennsylvania has been a steady, rational leader in managing the epidemic. Wolf has responded to the pandemic with powerful, clear, science-based guidance for the citizens of his state.

We feel as though Dr. Wolf brings together a strong strategic sensibility, tremendous empathy, and thoughtfulness in his leadership. He is a stellar Humphrey awardee for our times, exemplifying how well a doctorate in political science can lead to a proud life in public service.

\section{JAMES MADISON AWARD}

The James Madison Award is presented triennially to an American political scientist who has made a distinguished scholarly contribution to political science. Award Committee: Ayse Zarakol, chair, University of Cambridge; Steven S. Smith, Washington University in St. Louis; Susan Welch, Pennsylvania State University. Recipient: John Mearsheimer, University of Chicago.

Citation: After some consideration of all worthy nominees, the committee is delighted to select John J. Mearsheimer for the 2020 James Madison Award. Mearsheimer is currently the R. Wendell Harrison Distinguished Service Professor of Political Science at the University of Chicago, where he has taught since 1982. He is widely recognized as one of the leading International Relations scholars in the world and also a prominent public intellectual. Mearsheimer has written six books (including the very influential The Tragedy of Great Power Politics (2001)) and dozens of scholarly articles in leading journals. He is one of the most cited
IR scholars in the discipline, but his works are read well beyond the academy as well. As Stephen M. Walt noted in his nomination letter, John J. Mearsheimer "casts a very long shadow indeed."

\section{CAREY MCWILLIAMS AWARD}

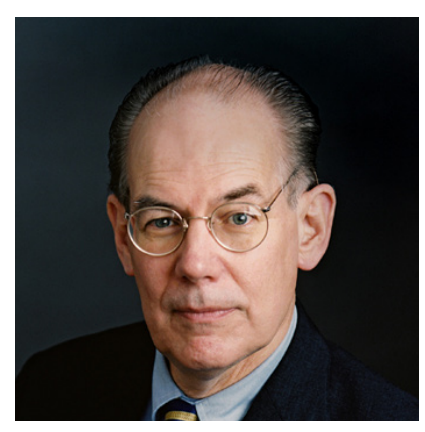

The Carey McWilliams Award is given annually to honor a major journalistic contribution to our understanding of politics. The winner should have a distinguished public service career in media and political science and should illumine certain key elements identified with McWilliams, which include intellectual forthrightness and political independence. Award Committee: Holli A. Semetko, chair, Emory University; Markus Prior, Princeton University; Tracy Sulkin, University of Illinois at Urbana-Champaign. Recipients: Judy Woodroff and Gwen Ifill (posthumously), PBS NewsHour.

Citation: In 2013, Judy Woodruff and Gwen Ifill, an award-winning Black journalist who passed away in 2016 shortly after the election, were the first women to coanchor a network broadcast. According to Katie Rogers writing in The New York Times, the PBS program is distinctive for a number of reasons beyond being the first to be coanchored by two talented women:

"Aside from its slower-paced broadcast, 'NewsHour' is distinct for another reason: its newsroom is majority female. Fifty-nine journalists are women, and 55 are men. The anchor and the executive producer are women. Many of the program's regular contributors-Marcia Coyle, Tamara Keith and Amy Walter among them-are women. Several 'NewsHour' journalists say this has created a more diverse report."

Gwen Ifill was an award-winning national political journalist who cohosted and managed the PBS NewsHour from 2013 until illness prevented her from continuing. In commenting on her extraordinary life and accomplishments in a PBS NewsHour report, President Obama praised her for her work as a journalist and as a role model and said that she has done her country a great service.

After graduating from Simmons University, Ifill's early career in the press included working with the Washington Post and later The New York Times, where she covered the White House. She moved to NBC in 1994, and in 1999 she became the first Black woman to host a national talk show as moderator of the PBS program "Washington Week in Review." She moderated the 2004 and 2008 vice presidential debates. Ifill's book, The Breakthrough: Politics and Race in the Age of Obama, was published on January 20, 2009, the day President Obama was inaugurated. She has received numerous awards for her work in journalism and was also the recipient of more than 20 honorary doctorates. This year, she was also honored on a US postage stamp. 
Judy Woodruff is the current anchor and managing editor of PBS News Hour. Working as a broadcast journalist since her graduation from Duke University in 1968, where she was a political science major, Woodruff has reported on every US presidential election since 1976. After working in local television news

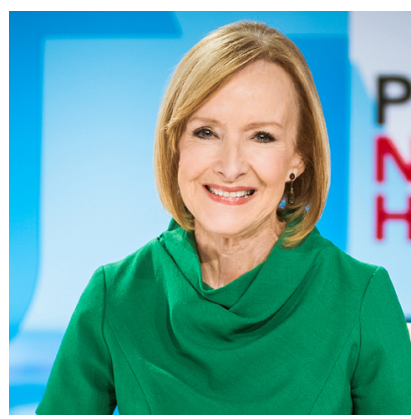

in Atlanta, Woodruff reported on Jimmy Carter's presidential campaign for NBC in 1976. She became White House correspondent for NBC shortly after President Carter's inauguration and moved to Washington, DC. Her book, This is Judy Woodruff at the White House, published in 1983, describes her work as a reporter. She moved to PBS in 1983 where she reported on national politics and hosted "Frontline with Judy Woodruff," and moderated the 1988 vice presidential debate. In 1993, Woodruff moved to CNN where she reported on national and international politics and served as coanchor for special coverage on events such as 9/11, the War in Afghanistan and the Iraq War.

After leaving CNN in 2005, and semesters conducting research at the Shorenstein Center on Media, Politics and Public Policy, and teaching at the Sanford School of Public Policy at Duke, she hosted a monthly news program on Bloomberg Television called "Conversations with Judy Woodruff." Woodruff returned to PBS in 2006 to work on what was then called the "NewsHour with Jim Lehrer" as a senior correspondent and was a rotating anchor of the program until 2013, when she became coanchor of the NewsHour with Gwen Ifill. Woodruff is the recipient of numerous awards, including honorary degrees from Duke University and the University of Pennsylvania. She is also an elected member of the American Academy of Arts and Sciences, and the Council on Foreign Relations.

\section{Book Awards}

\section{APSA-IPSA THEODORE J. LOWI FIRST BOOK AWARD}

The APSA-IPSA Theodore J. Lowi First Book Award is for the best first book in any field of political science, showing promise of having substantive impact on the overall discipline. Award Committee: Ferdinand Müller-Rommel, chair, Leuphana Universität; Ana De La O Torres, Yale University; Gary Herrigel, University of Chicago. Recipient: Rachel Augustine Potter, University of Virginia

Citation: Dr. Potter's publications have appeared in the Journal of Politics, Journal of Law, Economics, \& Organization, International Studies Quarterly, and Journal of Public Policy. She holds degrees from the University of Michigan, the University of Southern California, and Boston College, among others. In the 2018- 19 academic year, she was a visiting scholar at the Center for the Study of Democratic Politics at Princeton University.

Dr. Potter's first book, Bending the Rules: Procedural Politicking in the Bureaucracy, explores how unelected bureaucrats leverage procedures in order to exercise influence in the policymak-

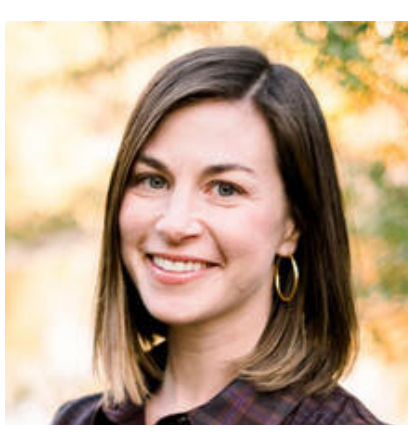
ing process of the Congress, the president and the courts. She represents a very innovative argument about bureaucratic discretion. The empirical findings of this book draw from multiple methodologies and accumulated cross-field research. The book illuminates in an excellent way our understanding of how government policy decisions are

made by public agencies.

\section{RALPH J. BUNCHE AWARD}

The Ralph J. Bunche Award is given annually for the best scholarly work(s) in political science that explores the phenomenon of ethnic and cultural pluralism. Award Committee: Tatishe Nteta, chair, University of Massachusetts Amherst; Emily Farris, Texas Christian University; Debra Thompson, McGill University. Recipient: Davin Phoenix, University of California, Irvine

Citation: For decades, scholars of political participation have argued that the low levels of African American political participation in a wide variety of domains (e.g., turnout, contacting officials, donating, volunteering, and attending meetings) reflects the relative dearth of African American civic skills and socioeconomic resources when compared to white Americans. In The Anger Gap: How Race Shapes Emotion in Politics, Davin Phoenix investigates the role that emotions, most notably anger, play in accounting for the racial divide in political participation in the United States. Drawing on insights from African American political thought, history, political communication, psychology, and political science and employing a multi-method approach, Phoenix argues that the racial divide in participation is a reflection of the gap between African Americans and whites in the mobilizing emotion of anger. Phoenix deftly shows how the stereotype of the "angry black man/woman" has and continues to preclude African Americans from accessing, expressing, and employing the emotion of anger-an emotion that has been used successfully as a tool by white Americans to mobilize political support among elected officials to effect beneficial political change. According to Phoenix, the result of this "anger gap" in public opinion is continved racial inequality in the US and the lack of receptivity to African American political demands by elected officials.

The Anger Gap: How Race Shapes Emotion in Politics is a nuanced, encompassing, and thorough analysis of African Amer-

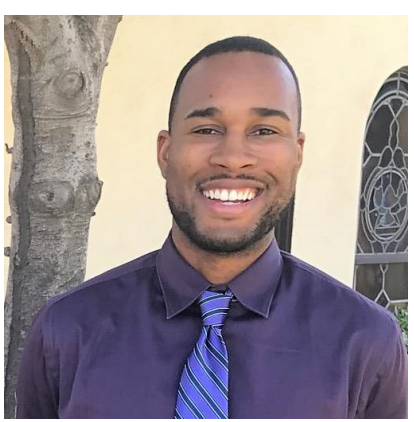
ican public opinion, thought, and political behavior in the 21 st century. Phoenix's argument concerning the mobilizing and transformative effect of anger on US politics is not only timely, but prescient, as evidenced by the emergence, spread, and influence of the \#BlackLivesMatter movement in the US. The commit- 
tee unanimously agreed that in line with the tenets of the Ralph J. Bunche Award, Davin Phoenix's The Anger Gap: How Race Shapes Emotion in Politics not only breaks new ground in the empirical and scholarly study of African American public opinion, but assists the public in better understanding the nature and origins of a contemporary African American-led social movement that seeks to establish the social justice, equality, and protections promised in nation's founding documents and most cherished values.

\section{ROBERT A. DAHL AWARD}

The Robert A. Dahl Award recognizes an untenured scholar(s) who produced scholarship of the highest quality on the subject of democracy, including books, papers, and articles. Award Committee: Rachel Beatty Riedl, chair, Cornell University; Agustina Giraudy, American University; Imke Harbers, University of Amsterdam; Eva Sørensen, Roskilde Universitet. Recipient: Ashley Nickels, Kent State University.

Citation: Ashley Nickels's Power, Participation and Protest in Flint, Michigan: Unpacking the Policy Paradox of Municipal Takeovers exemplifies the model of Dahl's inquiry into local politics to illuminate how democracy does or does not function to serve its citizens. Nickels dives into the emergency takeover and water crisis in Flint, Michigan, to demonstrate how technical and managerial arms of the government use moments of emergency to avoid accountability and diminish democracy. This book speaks powerfully to contemporary global politics of emergency health

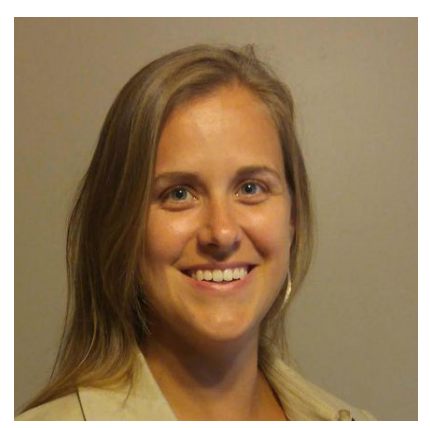

management and the broader role of autocratic technical solutions in place of democratic responsiveness. It could not be more salient and timely, as we face national and international questions about the role of the administrative and coercive state and their relation to citizens' safety, security, and well-being.

This deeply empirical account of municipal takeover in Flint, Michigan demonstrates how managerial governance can be used to advance elite interests. But Nickels also points to the role of community activists, and the role that participation and protest can play in demanding quality governance and reform. In identifying the space between public administration and politics, Nickels shows the importance of monitoring administration in the name of democracy and speaking to power to fulfill its promise.

\section{GLADYS M. KAMMERER AWARD}

The Gladys M. Kammerer Award is given annually for the best book published during the previous calendar year in the field of US national policy. Award Committee: Diane J. Heith, chair, St. Johns University; Daniel Gillion, University of Pennsylvania; Bryan Schaffner, Tufts University. Recipient: Amy E. Lerman, University of California, Berkeley.

Citation: In Good Enough for Government Work: The Public Reputation Crisis in America (And What We Can Do to Fix It), Lerman offers one of the most riveting books to date on how the government's reputation can shape citizens' perceptions on public policy and governmental services. The book is an engaging read that is well-argued, cleverly developed, and flawlessly executed. It deftly integrates a framework that has long been applied to understanding how businesses craft their reputations among consumers and uses it to explain why much of the public is so reluctant to turn to the federal government to solve its problems. Using an impressive combination of longitudinal survey data and experiments, Lerman convincingly demonstrates that the government's poor reputation

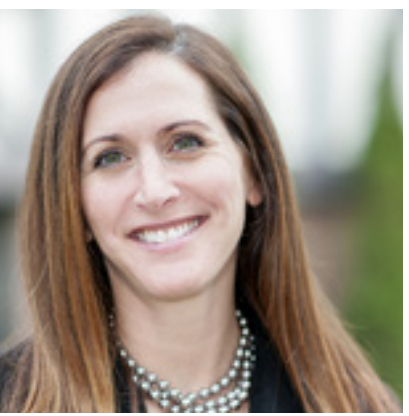
doesn't merely manifest in poor evaluations from citizens, but that it also has practical consequences by leading Americans to opt-out of government run programs altogether. It is an impressive work which engenders rethinking regarding the interplay between public attitudes and policy outcomes. The insights are particularly apt for understanding the current COVID- 19 crisis, both in terms of how the public takes a skeptical view of what government can actually do to help, but also for how the crisis may further damage the government's reputation in the future.

\section{VICTORIA SCHUCK AWARD}

The Victoria Schuck Award is given annually for the best book published on women and politics. Established to honor Victoria Schuck's life-long commitment to women and politics, this prize recognizes and encourages research and publication in this field. Schuck earned her PhD in 1937 from Stanford University and played a leading role in opening doors for women in the profession. She was not only an outstanding mentor for women, but her service in senior administrative roles at Mount Holyoke College and Mount Vernon College opened doors for future generations of women leaders. Award Committee: Caroline Beer, chair, University of Vermont; Nandini Deo, Lehigh University. Recipient: Melody Valdini, Portland State University.

Citation: Melody Valdini's The Inclusion Calculation: Why Men Appropriate Women's Representation changes the way we think about gender and politics. This book shifts the focus from the institutional, structural, and cultural factors that impact women's representation to the interests and incentives of male gatekeepers. She asks, "Why and under what circumstances do members of the 'in' group allow and even encourage members of the 'out' group to be in the government?" While Valdini acknowledges that there may be some 'angels' who work for gender equality even if

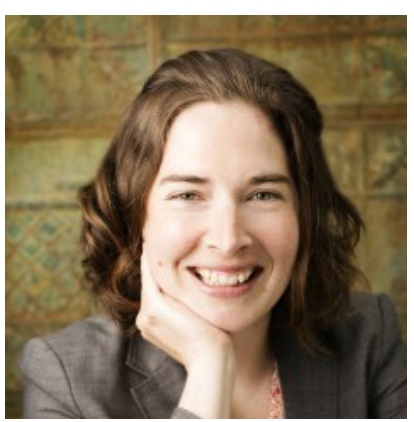
it is not in their own interests, most politicians are rational opportunists who do not explicitly oppose women in politics, but also do not actively work towards inclusion. She argues that women's representation is the result of a calculation of the costs and benefits to male gatekeepers of including women. The theoretical sections 
of the book clearly outline the factors that affect this calculation.

The costs of inclusion include the displacement of incumbents, threat to the power and resources of the current male elite, and the potentially negative electoral impact of women candidates, because of the perceived incongruity of stereotypical female characteristics with governance. Responsiveness to social movement demands and international pressure may create costs or benefits for including women. The inclusion calculation can change dramatically if there is a crisis of legitimacy. When parties lose legitimacy because of corruption scandals or the undermining of democratic practices, stereotypical female characteristics become more valuable, and the costs associated with including women decline. In such a context, stereotypical female characteristics become an asset rather than a liability in the inclusion calculation. Valdini's framing helps to provide a unified theoretical explanation for many of the empirical findings of existing research into representation, stereotypes, political parties, and corruption.

The empirical chapters provide brief case studies and statistical analyses to illustrate the effect of corruption scandals and declining democratic rights on the inclusion calculation. The book is clearly written and accessible to a wide range of readers, including undergraduate students. The committee believes that one asset of this book is the likelihood that it will launch important new scholarship. We hope that Valdini's framework will be extended to develop intersectional analyses of representation. The components of the inclusion calculation are clearly and persuasively articulated. They can easily be adapted to a wide range of circumstances and tested in many different ways. We believe this book will usher in an important new research program for the study of women's representation.

\section{WOODROW WILSON FOUNDATION AWARD}

The Woodrow Wilson Award is given annually for the best book on government, politics, or international affairs. The award, formerly supported by the Woodrow Wilson Foundation, is sponsored by Princeton University. Award Committee: Dan Posner, chair, University of California, Los Angeles; Laurel Harbridge-Yong, Northwestern University; Elizabeth Rigby, The George Washington University. Recipient: Amy E. Lerman, University of California, Berkeley (pictured under the Kammerer award citation).

Citation: The committee unanimously selected Amy E. Lerman's book Good Enough for Government Work as the winner of the 2020 APSA Woodrow Wilson Award. In this beautifully written, carefully composed book, Amy Lerman explores how the reputation of government is itself an impediment to the government's ability to achieve the common good. When people have persistently negative views about government, and these views are resistant to change, people may opt out of public goods, thus reducing their quality and resulting in a self-fulfilling prophecy of negative views of government programs. Drawing on social psychology, public opinion research, and crisis management in the business world, Lerman analyzes these questions in a creative and compelling way. The book combines evidence from survey experiments that isolate the key treatments of interest; field experiments that leverage a partnership with HealthSherpa.com (to compare sign up rates with healthcare.gov) to test how framing the policy as publicly or privately provided affects policy uptake; and quasi-natural experiments comparing Princeton Township and Princeton Borough, as well as different size dwellings in Chicago, to study people's actual experiences with publicly versus privately provided waste management services. The committee came away from reading Lerman's book feeling like we had acquired a nugget of truth about how the world works.

This masterful book provides valuable insights for scholars and for policymakers. Lerman achieves the gold standard for rigorous research using cutting edge methods while presenting the work in a way that makes it accessible and compelling.

\section{Dissertation Awards}

\section{GABRIEL A. ALMOND AWARD}

The Gabriel A. Almond Award is given annually for the best dissertation in the field of comparative politics. The award was created in recognition of Gabriel Almond's contributions to the discipline, profession, and association. Almond's scholarly work contributed directly to the development of theory in comparative politics and brought together work on the developing areas and Western Europe that prevented splintering into an array of disparate area studies. Award Committee: Dominika Koter, chair, Colgate University; Diana Fu, University of Toronto; Mariela Szwarcberg Daby, Reed College. Recipient: Rachel A. Schwartz, University of Wisconsin-Madison.

Citation: This theoretically innovative dissertation asks an important 'how' question: How does civil war shape state development in the long run? Schwartz argues that civil war introduces predatory rules of the game that undermine core state functions. Civil wars thus undermine state institutions not by destroying them but by introducing alternative institutional arrangements that undermine existing rules. The mechanism that Schwartz carefully outlines with the cases of three different administrative domains in Guatemala and Nicaragua is that in the context of escalating insurgent threat, counterinsurgent elites gain discretionary power, creating new institutions which serve their narrow interest. The

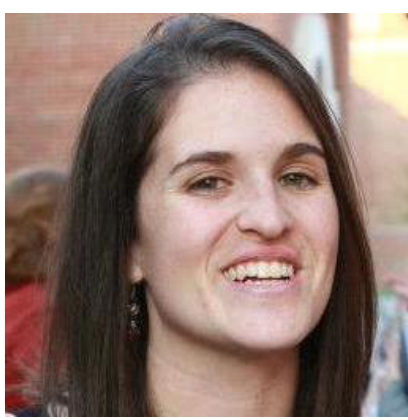
committee was impressed with the substantive contribution the thesis made to the literature on civil wars by focusing on institutional building. The thesis offers an original and substantive argument about the relationship between civil war and state weakness.

Schwartz conducted impressive research, collecting both fine-grained data from wartime state and private archives and conducting over 80 elite interviews. Schwartz adopts a comparative institutional approach across sectors and countries and relies on extended fieldwork to provide readers with a thick description of the cases and use of interviews combined with process tracing, comparative case study, and historical research to advance a persuasive argument. The thoughtful research design, the multimethod empirical strategy, and the careful analysis of evidence 
represent the highest quality work in our field. The committee particularly noted the extensive fieldwork over 20 months in Guatemala and Nicaragua. This research yielded an empirically rich dissertation theorizing wartime institutional change. It was refreshing to see such a careful study centered on Central America, a region underrepresented in current studies in the field, with findings that extend beyond Latin America.

\section{WILLIAM ANDERSON AWARD}

The William Anderson Award is given annually for the best dissertation in the general field of federalism or intergovernmental relations and state and local politics. The award was set up in honor of William Anderson, former APSA president, who was a leading American authority in the areas of local government, public administration, intergovernmental relations and the history of political science. He did much to shape teaching and research in these fields not only at his own university, but throughout the country. Award Committee: Megan Mullin, chair, Duke University; Tim Conlan, George Mason University; Tracy Osborn, University of lowa. Recipient: James Strickland, University of Michigan.

Citation: A feature of interest group politics across democratic political systems, multi-client lobbying has received little research attention. "Multi-Client Lobbying in the American States" tackles the topic by bringing theoretical innovation and ambitious data collection from the US states to understand why groups seek to hire lobbyists who advocate for multiple clients and the implications for interest representation. The dissertation first develops a measure of multi-client lobbying and then examines how legislative institutions and lobbying laws contribute to this type of advocacy activity. Strickland finds that these contextual conditions matter less than group-specific factors. In particular, public interest groups seeking collective benefits (e.g., environmental protection, government ethics, criminal justice reform) are more likely to hire single-client advocates in order to maintain ongoing lobby presence in the legislature and internal credibility with members or other stakeholders. Finally, the dissertation turns back to institutional conditions by examining the revolving door, showing that the value of hiring a former legislator to lobby lessens where member turnover is high, demonstrating an important caveat to our knowledge about the revolving door that has been based mostly on evidence from the US Congress.

The dissertation presents an ideal case of comparative state analysis. It treats states as intrinsically important venues for policy making activity that affects group interests while leveraging institutional and legal variation in theoretically informed ways that can transport to other levels and systems of government. The committee congratulates Strickland on making a sophisticated contribution to interest group theory while addressing an aspect of practical politics that has implications for all areas of state-level public policy.

\section{EDWARD S. CORWIN AWARD}

The Edward S. Corwin Award is given annually for the best dissertation in the field of public law. The Corwin award is for the best doctoral dissertation completed and accepted during that year or the previous year in the field of public law, broadly defined to include the judicial process, judicial behavior, judicial biography, courts, law, legal systems, the American constitutional system, civil liberties, or any other substantial area, or any work which deals in a significant fashion with a topic related to or having substantial impact on the American Constitution. Award Committee: Daniel Naurin, chair, Oslo University; Pamela C. Corley, Southern Methodist University; Michael J. Nelson, Pennsylvania State University. Recipient: Tommaso Pavone, Princeton University

Citation: This dissertation convincingly argues that the main theories of European legal integration got it wrong at the micro level: the engines of integration were not ambitious national judges, eager to challenge their own governments and judicial superiors by invoking European law and referring questions to the Court of Justice of the European Union. Instead, Pavone shows, national judges more often try to avoid the European route, due to excessive workload, insufficient understanding of European law and constraints stemming from their role in the national judiciary. Indeed, the drivers of integration through

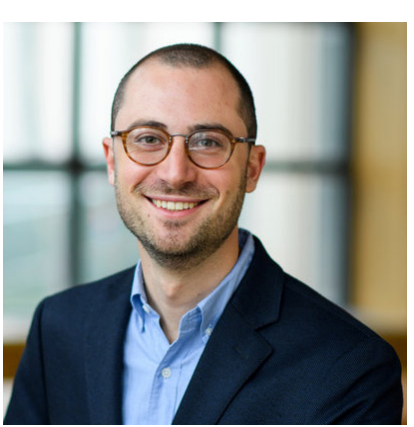
law were often the "Euro-lawyers"; a relatively small group of activist lawyers, who sought out suitable clients willing to break national laws and who cajoled reluctant local judges into activating the EU court. Pavone also commendably nuances his own story, demonstrating the shifting roles of lawyers over time and the uneven geographic integration of EU law, depending on local economic circumstances.

This is a remarkable dissertation, both in terms of theory development, research design, scope, and style. Besides rewriting the history of European legal integration, "The Ghostwriters" also makes important contributions to theories of legal mobilization and political lawyering beyond the European Union. Pavone builds his narrative on a set of carefully selected case studies and on a wide variety of data and methods, including archival studies, geospatial analysis and more than 350 interviews in Italy, France, and Germany. His way of communicating qualitative field work is unprecedented. Stories are told by long excerpts of conversations, by pictures and by descriptions of court rooms and crowded office spaces that carry a literary quality. The narrative is so persuasive because the judges and lawyers can speak directly to the reader. It is a dissertation of the highest quality.

\section{HAROLD D. LASSWELL AWARD}

The Harold D. Lasswell Award is given annually for the best dissertation in the field of public policy. Award Committee: Susan L. Moffitt, chair, Brown University; Isabelle Engeli, University of Exeter; George Hoberg, University of British Columbia. Recipient: Shiran Victoria Shen, Stanford University.

Citation: This outstanding dissertation provides a model of 
impactful public policy scholarship grounded in political science. This work exemplifies the ideals of the Lasswell Award in several respects. By providing a compelling, novel explanation for vari-

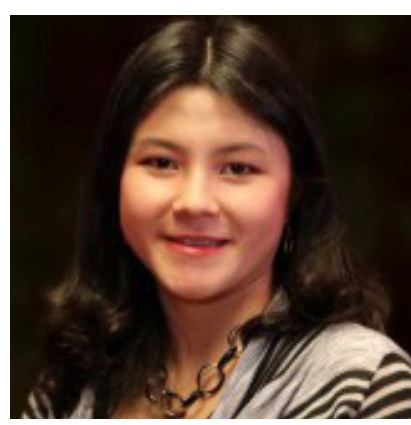

ation in air quality over time, this dissertation tackles an important, timely policy puzzle: air pollution constitutes the largest, current environmental problem facing the global community with impacts that reverberate across jurisdictions and across policy domains. To address its important policy puzzle, this dissertation marshals a truly impressive original dataset and deploys a novel empirical strategy. This work both offers a new approach to measuring air quality over time and seriously integrates its archival material and interviews into the analysis. In doing so, the dissertation truly embodies high quality mixed methods research and demonstrates the explanatory power that mixed methods research can yield. This dissertation also provides a model of how to present cutting edge methodological work in broadly accessible terms. The author's work is both unfailingly rigorous and beautifully written, which together augment the dissertation's impact. This dissertation also stands as a model for how to use political science theory to help explain policy problems. By considering and combining multiple policy goals with frontlines implementers' career incentives, the author expands on the conventional principal-agent approach to implementation in novel and useful ways. This work holds real promise of having broad impact well beyond environmental policy and in many geographic contexts outside of the dissertation's main focus on China.

\section{E.E. SCHATTSCHNEIDER AWARD}

The E.E. Schattschneider Award is given annually for the best doctoral dissertation completed and accepted during that year or the previous year in the field of American government. This award was set up in honor of Elmer Eric Schattschneider, a former APSA president, and widely published and respected political scientist. Award Committee: David A. Hopkins, chair, Boston College; Pearl K. Dowe, Oxford College, Emory University; William G. Howell, University of Chicago. Recipient: John Dearborn, Yale University.

Citation: In this exhaustive and illuminating dissertation, John Dearborn investigates how a singular idea-namely, that presidents uniquely represent national interests-has shaped not only our understanding of the American presidency, but the efforts of legislators to remake it. This notion of presidential representation, as Dearborn calls it, became powerful enough to convince members of Congress to grant the president broad agenda setting authority over the budget, trade, the federal bureaucracy, and the domestic economy. His thorough research and sharp analysis helps solve the historical puzzle of why bipartisan congressional majorities became willing to cede wide policy-making capacity to an increasingly powerful executive branch during the first half of the 20th century. After the presidential scandals of the 1960s and 1970s, however, the idea of the representative president lost its purchase on Capitol Hill, and legislators, not coincidentally, became less deferential to executive autonomy.

"The Representative Presidency: The Ideational Foundations of Institutional Development and Durability" is much more than an accounting of legislative debate, however. It is a tribute to the power of ideas in American politics and the ongoing and contested efforts of successive generations of politicians to grapple with constitutional legacies. Responding to previous scholarship that often treated presidential-congressional relations as a mere product of partisan alliances and ideological commitments, Dearborn convinc-

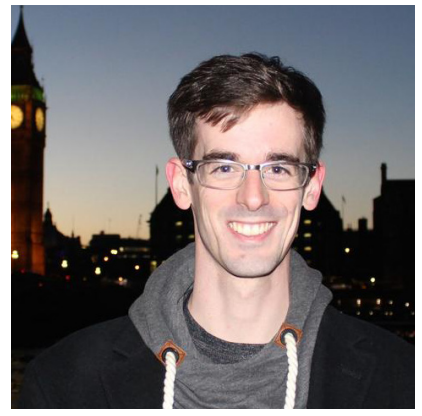
ingly shows that ideas about representation and form matter in our politics, and that these ideas have lasting consequences for the design of our nation's most powerful political office.

\section{KENNETH SHERRILL PRIZE AWARD}

Through APSA's Centennial Center for Political Science and Public Affairs, the Kenneth Sherrill Prize Award recognizes the best doctoral dissertation proposal for an empirical study of lesbian, gay, bisexual, or transgender (LGBT) topics in political science. The purpose of this prize is to encourage and enable empirical work on LGBT topics by graduate students, and to broaden the recognition of this work within political science. Award Committee: Gary Mucciaroni, chair, Temple University; Kelly Kollman, University of Glasgow; Douglas Page, Gettysburg College. Recipient: Kristopher Velasco, University of Texas at Austin.

Citation: We are excited to award Kristopher Velasco with the Kenneth Sherrill Prize because of his dissertation project's substantial contributions to the social scientific study of LGBT+ movements. Moving beyond 'progress narratives' concerning the development of rights, Velasco examines the collision between LGBT+ and antiLGBT+ movements, which produces a variety of policy outcomes with tremendous impacts on marginalized people's day-to-day lives. He argues that LGBT+ transnational advocacy networks precipitated homophobic advocacy networks. Networks focused on 'family', 'anti-imperialism', and 'children' (FAIC networks) mobilized in order to frame LGBT+ rights as threats to nationalism and family values. LGBT+ advocacy networks in part fueled homophobic animus and provided conservative/nationalistic actors with legitimacy for their homophobic policies and bases to organize FAIC networks. Velasco provides a novel theoreti-

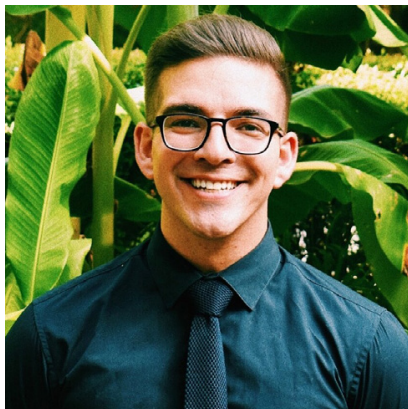
cal framework that allows us to better understand how competing networks produce varying policy outcomes. In particular, the framework points out how LGBT+ and FAIC networks both can be embedded in a society, creating contestation and intense competition regarding sexuality norms and public policy. Exam- 
ples of these societies include Italy, South Africa, and the United States. Velasco plans to unpack the contestation in these societies using a variety of data sources across multiple time periods, including content analysis of media sources as well as comparative policy analyses. We expect that these analyses will produce both compelling quantitative analyses and case study analyses.

\section{LEO STRAUSS AWARD}

The Leo Strauss Award is given annually for the best dissertation in the field of political philosophy. The fund was developed by former students of Strauss' who sought to recognize his extraordinary influence on generations of students and his contributions to the field of political philosophy. He was a major figure in the department of political science at the University of Chicago, where he taught from 1949 to 1967. Award Committee: Jill Frank, chair, Cornell University; Jeffrey Church, University of Houston; Claudia Leeb, Washington State University. Co-recipient: Elena Gambino, University of Minnesota, Twin Cities.

Citation: "'Presence in Our Own Land:' Second Wave Feminism and the Lesbian Body Politic" is a deftly argued and exciting intervention in and contribution to contemporary political theory and the history of feminist thought. Persuasively challenging dominant narratives of progress, according to which second wave feminists engaged in exclusionary politics of identity that were corrected by subsequent generations of feminist thinkers, Elena Gambino shows how lesbian feminists, beginning in the late 1970s, theorized and practiced a deeply intersectional politics, one that rested not on essentializing identity categories but on structures, relationships, and institutions capable of promoting coalition-building as a form of publicity.

To recover the diverse views and writers shaping second wave lesbian feminism, "Presence in Our Own Land" turns to the pages of Sinister Wisdom, 1976 to the present, a lesbian feminist magazine of poems, stories, essays, visual art, as well as reflection and self-assessment. Providing important historical context, this rich archive brings to light ongoing debates about racism, separatism, aesthetics, and political strategy, debates that reveal how contestation, specifically between Black and white lesbian feminists, fundamentally informed the contours and substance of the movement. Offering illuminating and compelling accounts of the ways

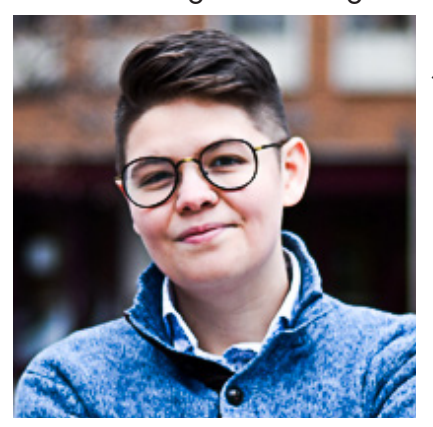

in which Audre Lorde, Bernice Johnson Reagon, Adrienne Rich, Barbara Smith, Monique Wittig, among others, altered contemporary understandings of injustice, authority, and political voice, Gambino theorizes a practice of coalition politics premised not on harmony, exemplarity, and inclusion, but on confrontation with persistent issues of inequality and broken trust, accountability, and repair. "'Presence in Our Own Land:' Second Wave Feminism and the Lesbian Body Politic" contributes critical conceptual resources to the field of political theory, while offering exceptionally timely strategies for any politics committed to solidarity across difference.

\section{Co-recipient: Tejas Parasher, University of Chicago}

Citation: "Self-Rule and the State in Indian Political Thought, $1880-1950^{\prime \prime}$ is an insightful and illuminating contribution to comparative political theory and the history of political thought. Through adroit historical analysis, Tejas Parasher reconstructs the discourse of self-rule in British India between 1880 and 1950, showing how, in a challenge to notions of parliamentary supremacy inherited from the French Revolution and held by Jawaharlal Nehru, Vallabhai Patel, and other leaders of the Indian National Congress, a diverse group of political thinkers, including Dadabhai Naoroji, M.K. Gandhi, and B.R. Ambedkar, advocated for new forms of political representation and economic controlbeyond European conceptions of the unitary nation-state-based on the distribution of law-making powers among central, local, and imperial legislative bodies.

Against longstanding analyses of the demand for self-rule in British India as a demand for centralized state-based sovereignty independent of imperial control, "Self-Rule and the State" valuably brings to light the important content and political and economic stakes of the argument among Indian political thinkers between divided versus unitary forms of popular sovereignty. Drawing on an impressive archive, including assembly debates between 1946 and 1950 leading up to the drafting of India's post-colonial constitution, Parasher demonstrates that even though the Indian founding

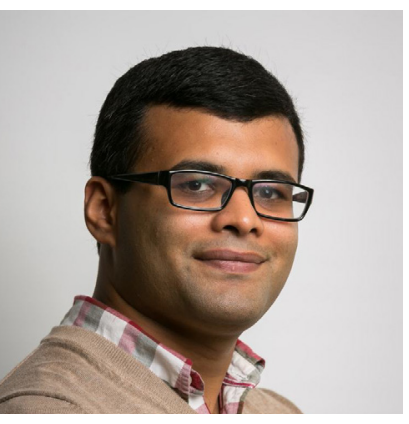
represented a triumph of unified governance, critiques of unitary sovereignty, along with their visions of socialist politics as alternatives to both Western European welfare states as well as the Soviet model of planning, were central to anti-colonial thinking on self-rule. By recovering federalist and socialist visions of anti-colonialism marked by discontinuities with a European past, "Self-Rule and the State in Indian Political Thought, 1880-1950" provides crucial intellectual resources for studies of decolonization in political and legal theory, global history, and international law, while paving the way for new configurations of post-colonial sovereignty and popular rule.

\section{MERZE TATE AWARD}

The Merze Tate Award (formerly the Helen Dwight Reid Award) is given annually for the best dissertation successfully defended during the previous two years in the field of international relations, law, and politics. Award Committee: David G. Victor, chair, University of California, San Diego and The Brookings Institution; Jennifer Hunt, Australian National University; Kathy Powers, University of New Mexico. Recipient: Erik Lin-Greenberg, Columbia University.

Citation: Lin-Greenberg's dissertation is an impressive look at the age-old question of how changes in technology affect the risks and conduct of war. Lin-Greenberg's focus is on the innovation of drones, and whether that technology makes it more or less likely for tensions to escalate into war. Theory points in many different directions. Many scholars and policy makers have 
thought that technologies that make war easier will also lubricate the process of crisis escalation. Lin-Greenberg takes a fresh look at this issue-building new theory and testing those theoretical ideas with diverse methods. On the substance, the dissertation stands out for novelty. Lin-Greenberg argues that easier war-making does indeed escalate the use of force. But, the lack of humans on the platforms means that when shots are fired the need for reprisals is greater. Warfighting goes up and down, but it is also easier for militaries to keep things in check. Notably, this dissertation offers a model that can be replicated by scholars looking at other technologies and with other empirical tools. That is a gold standard for political science scholarship-new directions in theory, clever

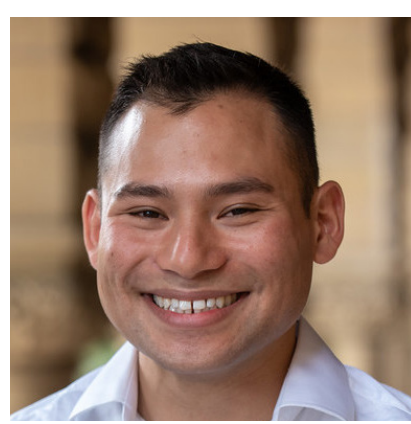

combinations of methods well aligned to testing theory, and transparent writing so that others can learn and build upon.

This dissertation was selected for the award on its own merits of relevance, importance, and quality. The Award Committee also notes that the topic reflects Merze Tate's interest in the role of weapons and peace-topics she wrote about in the late 1940s as the world grappled with the need to cap the volcano of armaments and the impacts of new weapons on the risks of war.

\section{LEONARD D. WHITE AWARD}

The Leonard D. White prize is awarded annually for the best dissertation successfully defended during the previous two years in the field of public administration. Award Committee: Jacqueline M. Chattopadhyay, chair, University of North Carolina, Charlotte; Daniel P. Hawes, Kent State University; Jessica N. Terman, George Mason University. Recipient: Angela Young-Shin Park, University of Kansas.

Citation: Dr. Park's dissertation examines the role that institutional arrangements play in supporting the successful implementation of sustainability programs by local governments. As the dissertation explains, sustainability initiatives aim to simultaneously advance economic, environmental, and equity goals. The importance of sustainability efforts-and the risk that they may fail due to the challenging, cross-department collaboration that they typically require-make it important to study which factors correlate to successful sustainability policy implementation. Dr. Park's dissertation studies this question through three papers, which respectively focus on the policy implementation stage, the policy evaluation stage, and the use of performance information in sustainability management.

The dissertation makes contributions to research on public management and collaborative governance, and the findings also have the potential to inform the practice of public administration in local government. The committee was also impressed by the close fit between the research question that each chapter set out to investigate and the data used in the analyses, and by the clear writing style used throughout.

\section{Paper and Article Awards}

\section{FRANKLIN L. BURDETTE/PI SIGMA ALPHA AWARD}

The Franklin L. Burdette/Pi Sigma Alpha Award is given annually for the best paper presented at the previous year's annual meeting. The award is supported by Pi Sigma Alpha. Award Committee: Daniel Pemstein, chair, North Dakota State University; Ray Block, Jr., Pennsylvania State University; Olga V. Shvetsova, SUNY, Binghamton University. Recipients: Kristen Kao, Göteborg University and Mara Redlich Revkin, Georgetown University.

Citation: "Retribution and Reconciliation: Attitudes Toward Rebel Collaborators in Iraq" addresses critically important, but difficult to study, questions about what determines citizens' post-conflict attitudes about the punishment of-and leniency toward-people who collaborated with rebel groups during periods of civil violence. Leveraging a survey experiment that they conducted in Mosul, Iraq after a three-year occupation by the Islamic State, the authors find that respondents prioritize collaborators' roles, rather than their identity characteristics, when weighing punishment and forgiveness. Surprisingly, they also find that preferences for retribution are largely invariant to personal exposure to violence. This work combines pressing policy relevance for peacebuilding in Iraq with strong research design and a novel theoretical frame that has general applications to work on transitional
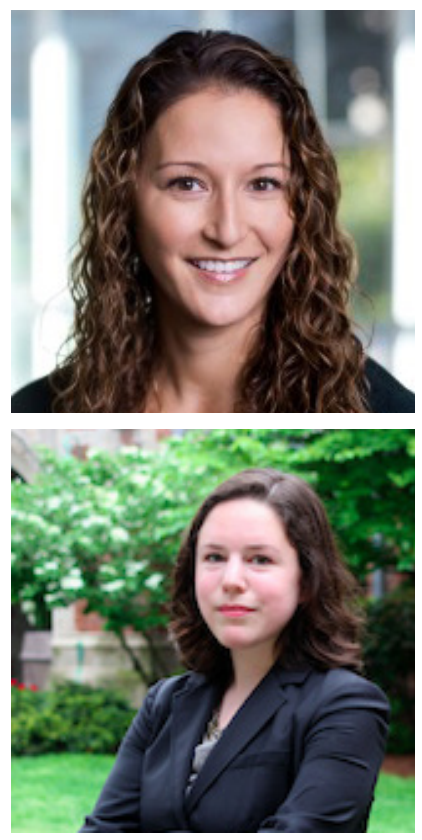
justice. By emphasizing the preferences of the everyday victims of rebel violence, rather than national politics, they focus our attention on a poorly understood, but crucial, constituency in the process of post-conflict peacebuilding. They also conceptualize collaboration broadly, eschewing a common tendency to study only the most violent forms of collaboration. We expect this work to resonate widely with both scholars and practitioners interested in post-conflict justice and peacebuilding.

\section{HEINZ EULAU AWARD: APSR}

The Heinz Eulau Award is given annually for the best article published in the American Political Science Review in the past calendar year. The award is supported by Cambridge University 
Press. Award Committee: Vera Eva Troeger, chair, University of Hamburg; Samara Klar, University of Arizona; Yonatan Lupu, George Washington University. Recipients: George Kwaku Ofosu, London Schools of Economics and Political Science.

Citation: In "Do Fairer Elections Increase the Responsiveness of Politicians?" George Kwaku Ofosu combines careful theoretical argumentation with novel experimental designs to examine whether high-quality elections increase political responsiveness. Within the context of Ghana, he shows that when elections are

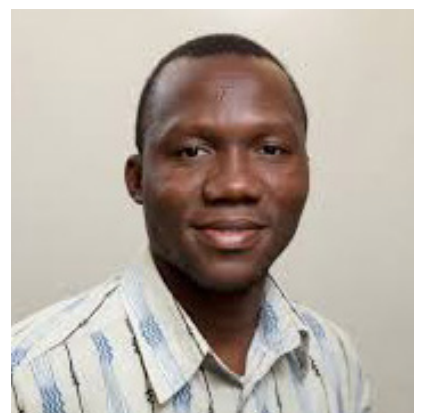
monitored and thus become fairer, politicians cannot win elections through outright manipulation. This, in turn, incentivizes candidates to invest resources into meeting the needs and gaining the support of their constitvents. Ofosu analyses 2,160 months of Constituency Development Fund spending of Ghanaian legislators by randomly assigning election-day monitoring during Ghana's 2012 elections. The sophisticated experiment-in-the-field design enables him to draw causal conclusions for Ghanaian politicians. He carefully discusses external validity and generalizability of his findings. The selection committee deemed this a very impressive and worthy article that combines careful theoretical work with a sophisticated research design that allows causal inference and extensive data collection. The article generates important and interesting academic results that are at the core of political science but also have real world implications and offer relevant policy recommendations.

\section{HEINZ EULAU AWARD: PERSPECTIVES ON POLITICS}

The Heinz Eulau Award is given annually for the best article published in Perspectives on Politics in the past calendar year. The award is supported by Cambridge University Press. Award Committee: Vera Eva Troeger, chair, University of Hamburg; Kathleen Bawn, University of California, Los Angeles; Jorgen Moller, Aarhus University. Recipients: Katherine Levine Einstein, David M. Glick, and Maxwell Palmer, (all Boston University).
Citation: Einstein et al. address an existing debate about how institutions, by facilitating community participation, can mitigate political inequalities in "Who Participates in Local Government? Evidence from Meeting Minutes." They explore new aspects of this question by compiling a unique dataset which registers thousands of instances of citizens speaking at planning and zoning board meetings concerning housing development and match these individuals to voter files. On this basis, they show that participation is unrepresentative, and that those who self-select into engaging in these debates are more prone to oppose new housing construction. Einstein et al. conclude that these participatory inequalities may contribute to rising housing costs, and that this has generally been overlooked by those who see this kind of community participation as buffer against political inequality. The selection commit-
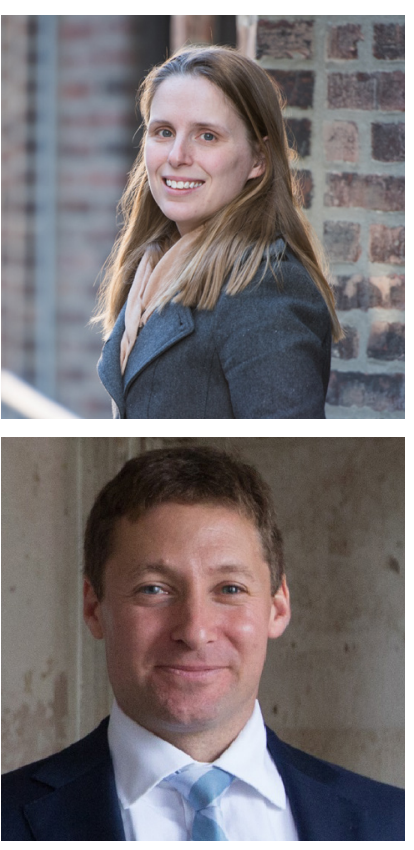
tee found this a very impressive article, which codes new data, interrogates it carefully, and arrives at interesting findings, with important real-world implications. It clearly presents a huge amount of work, and it has solicited a lot of interest already, whether measured by downloads, altmetrics or citations. This is the kind of work Perspectives on Politics was created to showcase: strong on an important question, which advances knowledge in a way of interest to specialists but written in a way that is transparent and broadly accessible. 